\title{
MECHANICAL PROPERTIES OF HAND-MAKING POLYESTER COMPOSITES
}

\author{
Anna Rudawska', Mateusz Malczarski ${ }^{1}$, Dana Stančeková ${ }^{2}$, Magd Abdel Wahab³, \\ Vladimira Schindlerová ${ }^{4}$
}

1 Lublin University of Technology, Faculty of Mechanical Engineering, ul. Nadbystrzycka 36, $20-618$ Lublin, Poland, e-mail: a.rudawska@pollub.pl, malczarski@gmail.com

2 University of Žilina, Faculty of Mechanical Engineering, Univerzitna 1, 010 26, Žilina, Slovak Republic, e-mail: dana.stancekova@fstroj.uniza.sk

3 Ghent University, Faculty of Engineering and Architecture, Technologiepark Zwijnaarde 903, B-9052 Zwijnaarde, Belgium, e-mail: Magd.AbdelWahab@UGent.be

${ }_{4}$ Technical University of Ostrava, Faculty of Mechanical Engineering, 17.listopadu 15, 70833 Ostrava - Poruba, Czech Republic, e-mail: vladimira.schindlerova@vsb.cz

Received: 2018.04.11

Accepted: 2018.05.15

Published: 2018.06.01

\begin{abstract}
The aim of this paper is to determine the effect of arrangement of fibreglass fabric plies in a polymer composite on a strength. Based on the experimental results, the real effect of plies arrangement and their most favourable configuration with respect to strength is determined. The experiments were performed on 4 types of handmade composites which had different fibre orientations and thicknesses. The first three of the composites had three plies of fabric. The plies arrangement in Composite I was unchanged, in Composite II the central ply had the $45^{\circ}$ orientation, while in Composite III the outside ply (tangential to the adhesive layer) was oriented at $45^{\circ}$. In contrast, Composite IV consisted of five plies with unchanged arrangement. Composite plates were first cut into smaller specimens and then after stabilizing, the composite specimens were subjected to strength tests. The highest tensile strength and elongation are obtained for Composite IV, which was the higher the thickness from the tested composite samples, but for this composite the tensile modulus was lowest value. Composite II has the lowest values of strength parameters among the tested composites, which contain three plies and central ply has the $45^{\circ}$ orientation.
\end{abstract}

Keywords: polymer composites, plies orientation, strength.

\section{INTRODUCTION}

Composites are applied in many branches of industry $[2,5,9,17,19,26,35,37]$. Composites can be strengthened with different types of fibres [11, 12 , $22,30,37]$. In this way an increase of some strength indicators of this composite is achieved [4]. Depending on the required strength, operating conditions, production method and other factors, the appropriate types of composite components are assorted: fibres and matrix. The fibres used for reinforcing composites can be: glass, carbonised, boron, aramid, organic, metallic or ceramic $[4,7,24,25,28,34,36]$.
Polymer-based composites reinforced with various fibres are applied in several industry branches such as $[2,8,10,12,17,35,37]$ :

- automotive branch (mainly glass fibres, carbon and organic fibres) - mainly in car-body elements, doors, bonnets and boot lid;

- different means of transport, such as railway - construction elements of railway cars and locomotives;

- aircraft branch (e.g. the main rotor blade and supportive rotor blade, fuselage elements and helicopter equipment, construction elements and sheathing, potable water installations and 
Table 1. Some mechanical properties of non-reinforced resin and laminate [20]

\begin{tabular}{|l|c|c|}
\hline \multicolumn{1}{|c|}{ Material } & \multicolumn{2}{c|}{ Strength [MPa] } \\
\cline { 2 - 3 } & Tensile strength & Compressive strength \\
\hline Non-reinforced resin polyester & $20-80$ & about 150 \\
\hline $\begin{array}{l}\text { Laminates obtained from fabric, test parallel to the direction of } \\
\text { the position of the fibres }\end{array}$ & about 200 210 \\
\hline The difference in the strength of the laminate and resin & $120-180$ & 60 \\
\hline
\end{tabular}

air-condition installations);

- $\quad$ aerospace industry (satellites aerials, pressure vessels);

- $\quad$ shipbuilding industry (hulls of ships);

- building industry (different types of containers and pipelines, bridge constructions and other).

Products made of materials such as fibreglassreinforced polymers play a significant role in industry [1]. Known as polymer composites, these materials are of vital importance in industry due to a wide range of potential combinations of their individual components [27]. These components include fillers and polymer matrix. The filler material can be made fibres, fabric, paper, and staple fibres [24], e.g. glass fibre, carbon fibre, also carbon nanofibres or boron carbides [7, 22, 25, 28, 31]. The polymer matrix can be made of resins, such as epoxy resins, polyester resins, phenol-formaldehyde resins or maleic resins [8, 20, 21, 29, 37]. The variety of resin and filler types provides an opportunity to fabricate diverse composite materials [24]. Most of them are designed for particular purposes depending on technical and operational aspects of a given composite $[6,13,18]$.

The character of used to strengthen glass greatly affects the strength of the obtained polyester laminate both because of the different possibilities of the fibers, their content in the laminate and method of forming, and the porosity of the product. However the manufacturing of laminates can be expensive because of the high labour requirement in the manual lay-up of plies [24].

The use of glass fabric due to their compact design allows to obtain laminates with relatively large content of glass, and therefore of considerable mechanical strength. Laminates of fabrics exhibit the warp and weft maximum mechanical properties, while at $45^{\circ}$ to the directions of these characteristics are much worse [20]. The various laminates, which have various the arrangements of plies and amount of plies, were tested. Polymer laminates which consist 16 plies (each ply is approximately $0.125 \mathrm{~mm}$ thick) with $(01 / 901)_{4 \mathrm{~s}}$ layup were tested by Katman et al. [16]. The polymer composites with 8 and 10 pre-impregnate plies of carbon and glass fibres in the same orientation were investigated by Bénard et al. [3].

The use of composites and other polymers usually poses bonding problems [32, 33]. Adhesive bonding is often preferred for joining composite laminates because the adhesive itself is often the same polymer as the resin matrix. Laminate configuration and properties affect adhesive stress and joint durability. In response, adhesive properties and thickness influence damage progression in the laminate [23].

In practice this rarely occurs axial stretching, and most often it is bending. By bending the beam on two supports, which runs the force is compression, and opposing - tension. It is therefore appropriate to adjust the ownership of materials. In Table 1 summarizes the mechanical properties of non-reinforced resin polyester laminate obtained from fabric, test parallel to the direction of the position of the fibres [20].

As is evident from the data provided in table 1 polyester resin is relatively resistant on the compression, and the bad - for stretching. Laminate of fabric is much better resistant for stretching. And the laminate with high resin content is also good on the compressive and is bed resistant on tensile. So it is not indifferent, on which side of the bending cross section will be the strengthening material. The example of bending laminates samples consisting of two layers of mats and one layer of fabric is shown in Figure 1.This sample supports distance was 4 centimeters, the thickness of the laminate polyester - 2 millimeters, the contents of the glass $-36 \% \mathrm{w} / \mathrm{w}$. Bending strength obtained for a sample of the compression side mat was 322 $\mathrm{MPa}$, while the reverse side - only $120 \mathrm{MPa}$. The difference of bending strength $\left(R_{g}\right)$ in both of these cases, for the same samples was significant.

This paper investigates the effect of arrangement of individual plies of fibreglass fabric in a composite material on the strength of hand-making composites. On the basis of the analysis of the studies specified the actual impact of the arrangement 

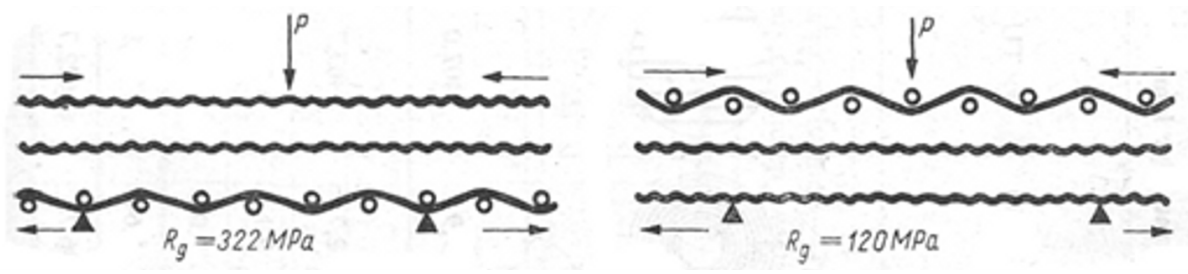

Fig. 1. The schema of bending laminates samples consisting of two layers of mats and one layer of fabric [20]

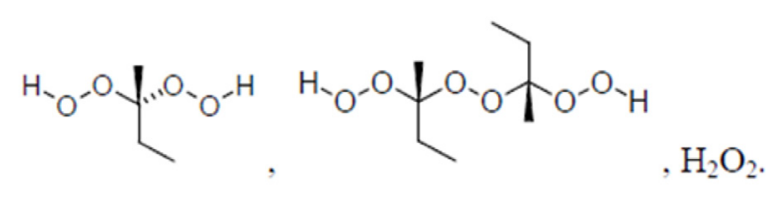

Fig. 2. Structure of Polimal 1094 resin [15]

of layers and the best of their arrangement affect strength of these composites. The one of main purpose is presents the some technological aspect of mechanical properties of hand-making composites.

\section{TEST METHODOLOGY}

\section{Characteristic of composites}

For the purpose of the study, four polymer composites made of two constituent materials were fabricated. The reinforcement material was plain weave fibreglass fabric $200 \mathrm{~g} / \mathrm{m}^{2}$, while the matrix material was POLIMAL 1094 polyester resin [14].

The first three of the composites had three plies of fabric. The plies arrangement in Composite I was unchanged, in Composite II the central ply had the $45^{\circ}$ orientation, while in Composite III the outside ply (tangential to the adhesive layer) was oriented at $45 .^{\circ}$ In contrast, Composite IV consisted of five plies with unchanged arrangement (Tab. 2).

\section{Mould design and preparation}

First, it was necessary to design a mould where a composite material was to be fabricated. The mould was made of multi-chamber polycarbonate with the dimensions $60 \times 60$. This popular material is widely used in the roofing and roof glazing of sports, industrial and commercial buildings, as it is very light and easy to process. Prior to creating a composite material, the mould was suitably prepared. First, the entire surface of the mould was degreased with acetone to remove dirt which accumulated during mould fabrication and other activities. Next, it was thoroughly coated with an anti-adhesive agent, Polsiform. After atomizing, the agent generated a thin layer of silicon oil on the surface of the mould. Besides having anti-adhesive proprties, the silicon oil has no negative effect on the processing and casues no defects in the finished product.

Prior to fabricating each composite material, cut-to-dimension fibreglass fabric and polyester resin (POLIMAL 1094, produced by Organika Sarzyna, Poland [14]) were mixed with Metox-50 curing agent. The ratio of mixing the resin and curing agent was 100:10. Particular care was taken to prevent introducing too many air bubbles into the mixture during this process.

Polimal 1094 is orthophthalic structural resin (Fig. 2), medium-flexible, accelerated, low emission of styrene and a colored indicator of cure. It is used in the production of glass laminates with a thickness of $5 \mathrm{~mm}$. Good curing requires the ambient temperature above $18^{\circ} \mathrm{C}$ and low humidity. It is accelerated resin having a relatively short and stable shelf life gel time.

Metox-50 is a peroxide initiator for copolymerization of unsaturated polyester resins and vinyl ester. This hardener contains methylethylketone peroxide and it is $20 \%$ solution in dimethylphthalate. It is used mainly with cobalt accelerators at environment. Due to the reduced the water content is recommended for curing gelcoats, polymer concrete and some polyester varnishes.

\section{Making of the composites}

After protecting the entire mould surface from adhesion, its inside was coated with a thin

Table 2. Characteristics of the tested polymer composites

\begin{tabular}{|c|c|}
\hline Designation of composites & Plies arrangement \\
\hline Composite (I) & $0 \% 0^{\circ} / 0^{\circ}$ \\
\hline Composite (II) & $0 \% 45 \% 0^{\circ}$ \\
\hline Composite (III) & $45 \% 0^{\circ} / 0^{\circ}$ \\
\hline Composite (IV) & $0 \% 0 \% 0^{\circ} / 0^{\circ}$ \\
\hline
\end{tabular}


a)

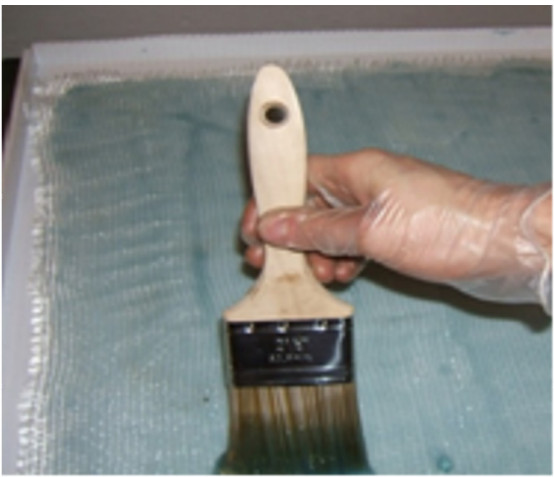

b)

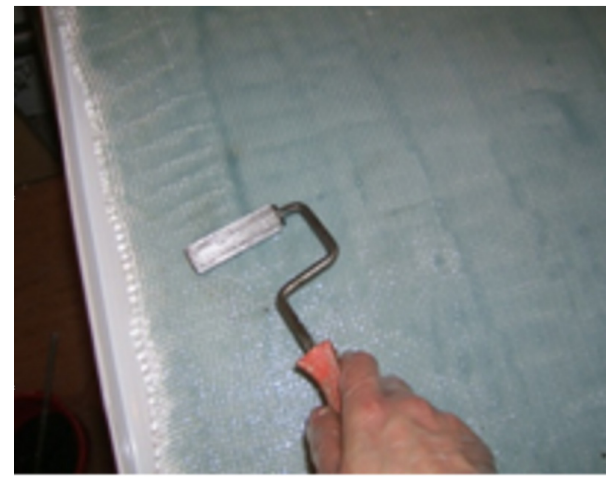

c)

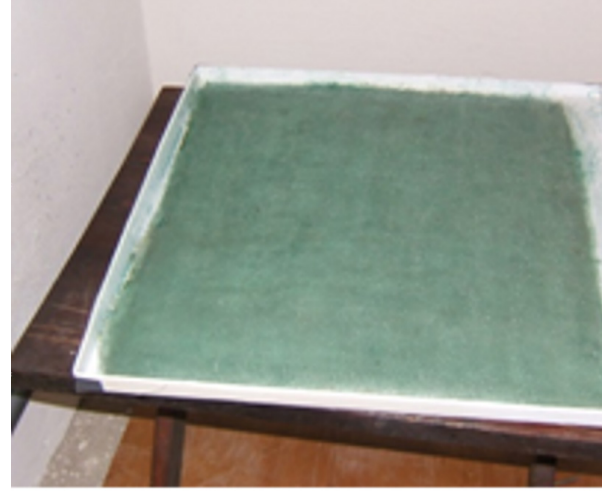

Fig. 3. Making of a composite material: a) application of resin to sucessive layers of fibreglass fabric using a brush, b) resin impregnation using a roller, c) composite material

layer of polyester resin, and the first ply of fibreglass fabric was laid out depending on the type of a composite to be made (Tab. 2). Next, another ply of resin was applied with a brush (Fig. 3a). To supersaturate the fabric with the resin and to remove air bells from the space between fibres, the whole material was subjected to rolling (Fig. 3b). This operation was repeated for two successive plies, with the fibreglass fabric laid out in accordance with the desired composite layup design.

In the course of the process, particular care was taken to spread the resin over the entire surface of the fabric as thoroughly as possible, ensuring that it is distributed evenly. The obtained composite material is shown in Figure 3c.

\section{Cutting and preparation of samples}

The four prepared composite materials were left to cure for 4 days. After that period, each composite was removed from the mould, cut and numbered. Each sample was assigned its own unique Roman numeral (I through IV) to indicate the number of a composite material and its serial number. The samples were cut by a FNU-50E milling machine. The cut composites were used four blade cutter mill with skew cuts in the working part of the CVD diamond coating for the assay JRT0600 a diameter of $6 \mathrm{~mm}$. The cut was implemented with the following technological parameters: RPM $9000 \mathrm{~min}^{-1}$ and a feed of $1000 \mathrm{~mm} / \mathrm{min}$.

\section{Description of polymer composite samples}

The experiments were performed on samples produced in compliance with the above procedure. Each sample had a length of $100 \mathrm{~mm}$ (L) and a width of $25 \mathrm{~mm}$ (w) (Fig. 4).

Their thickness ( $t$ ) varied depending of the number of plies. Composites I, II, III had a thickness of $2 \mathrm{~mm}$, while Composite IV had a thickness of $3 \mathrm{~mm}$. The samples are prepared to the following bonding process, but any standard was used to preparing the samples.

\section{Description of polymer}

The polymer composites specimens were subjected to strength tests on a testing machine ZWICK/ROELL Z150 in compliance with the standard DIN EN 527-1. The tests were conducted at the following parameters: tensile modulus crosshead speed $1 \mathrm{~mm} / \mathrm{min}$, crosshead speed $5 \mathrm{~mm} / \mathrm{min}$.

The following strength test results were analyzed: 


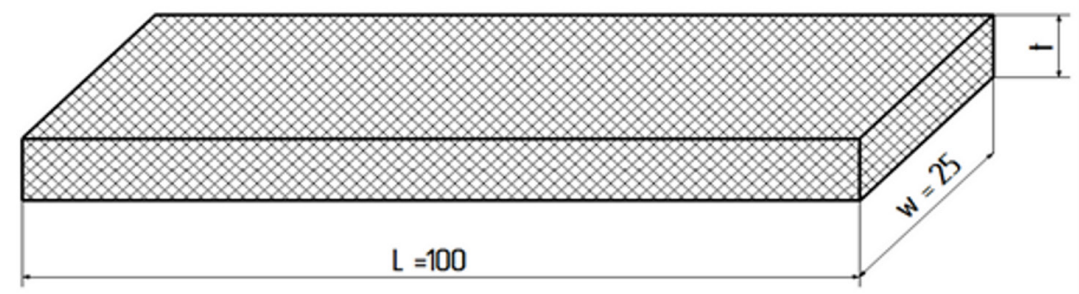

Fig. 4. Dimensions of the composites samples after cutting

- $\mathrm{E}$ - tensile modulus in $\mathrm{MPa}$,

- $\mathrm{R}_{\mathrm{p} 0.2}$ - elongation limit at disproportionate extension of $0.2 \%$,

- $\mathrm{R}_{\mathrm{m}}$ - tensile strength in MPa.

To perform strength tests, the prepared samples were mounted in helical-wedge chucks of the testing machine. Thereby fixed joints were then subjected to strength testing until their failure.

\section{RESULTS}

\section{Surface view}

The microscopic views of prepared composites were presented in Figs. 5-8. The photographs were made using the stereoscopic microscope NIKON SMZ 1500.

In Figure 5 and Figure 8 the microscopic photographs presented the plies which have $0^{\circ}$ orientation, but the different the amount of plies. It can be noticed that the composite IV ( 5 plies) is more compact structure than the composite I ( 3 plies). In microscopic view of composite II (Fig. 6) the $0^{\circ} / 45^{\circ} / 0^{\circ}$ plies arrangement was noticed. In Fig. $6 \mathrm{~b}$ it can be noticed the first $\left(0^{\circ}\right)$ and the second plies $\left(45^{\circ}\right)$. In Fig. 7 the first plie of $45^{\circ}$ orientation is observable.

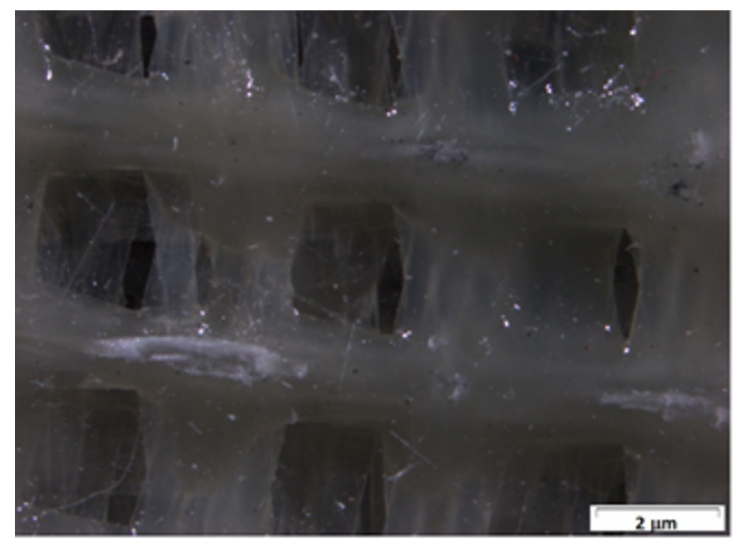

Fig. 5. Surface view of composite I: $0^{\circ} / 0^{\circ} / 0^{\circ}$ plies arrangement
It can be noticed that the composite IV (5 plies - Fig. 8) is more compact structure than the composite I (3 plies - Figs. 5-7).

\section{Tensile strength of polymer composite samples}

The results of strength test of the polymer composite samples are illustrated in Figs. 9-11.

The highest value of tensile modulus (Fig. 9) for Composite III $\left(0^{\circ} / 0^{\circ} / 45^{\circ}\right)$ was obtained (2255 MPa), while the lowest value of tensile modulus (1370 MPa) for Composite IV (5 plies

a)

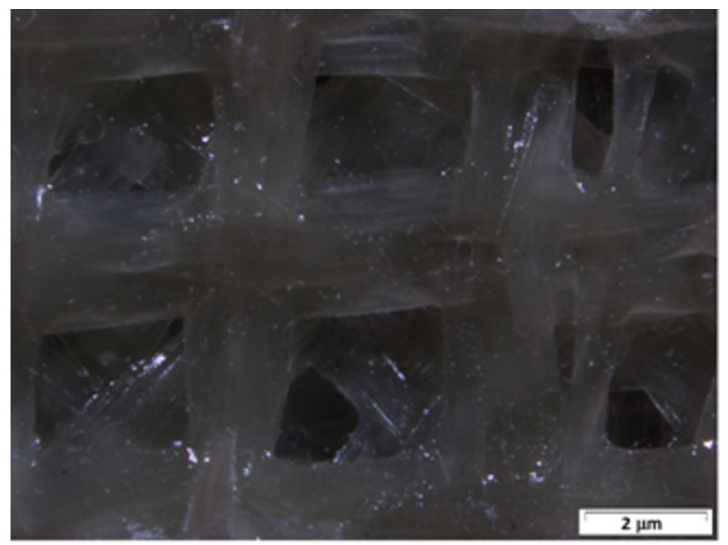

b)

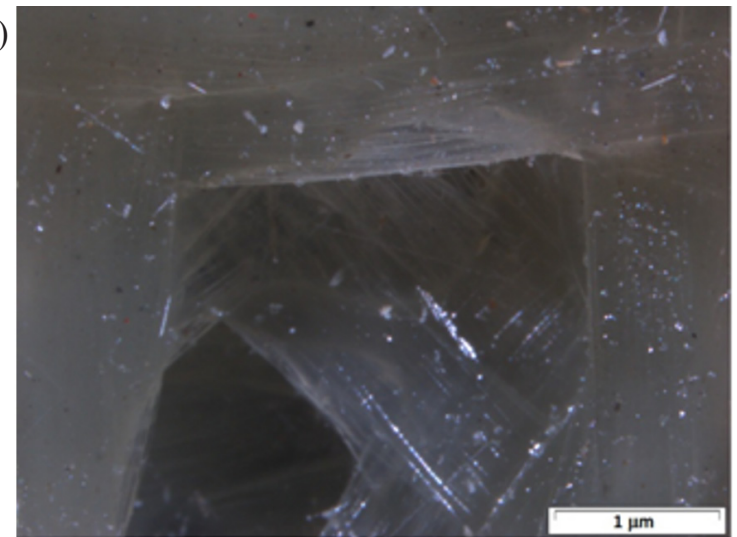

Fig. 6. Surface view of composite II: $0^{\circ} / 45^{\circ} / 0^{\circ}$ plies arrangement: a), b) 
a)

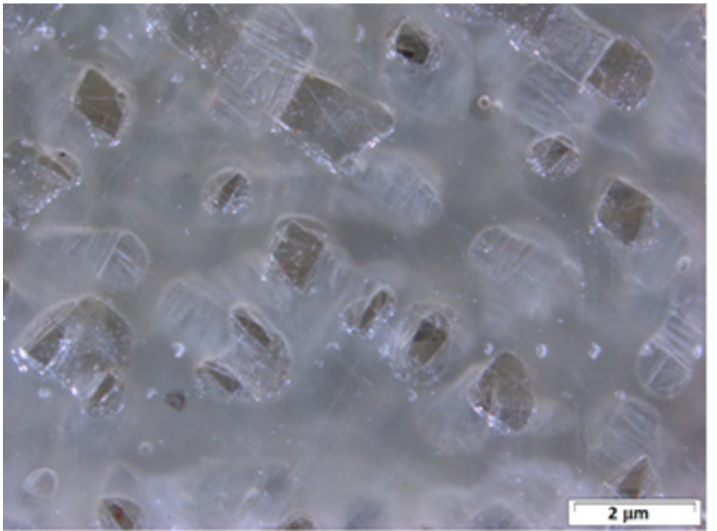

b)

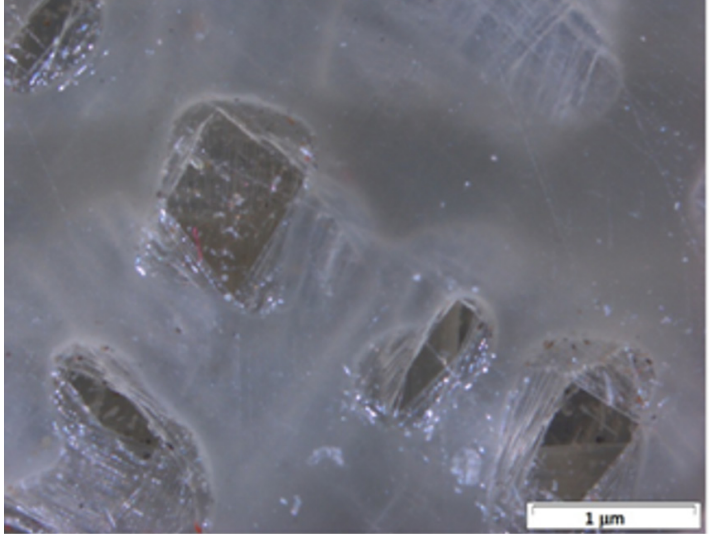

Fig. 7. Surface view of composite III: $45^{\circ} / 0^{\circ} / 0^{\circ}$ plies arrangement: $a, b)$ a)

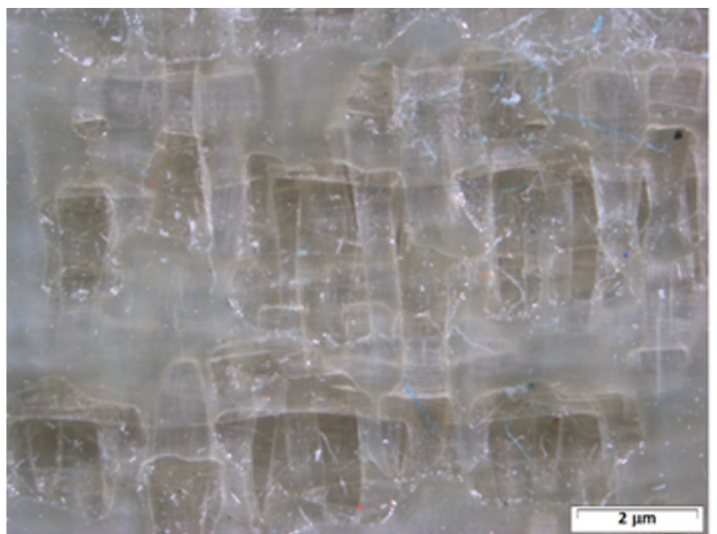

b)

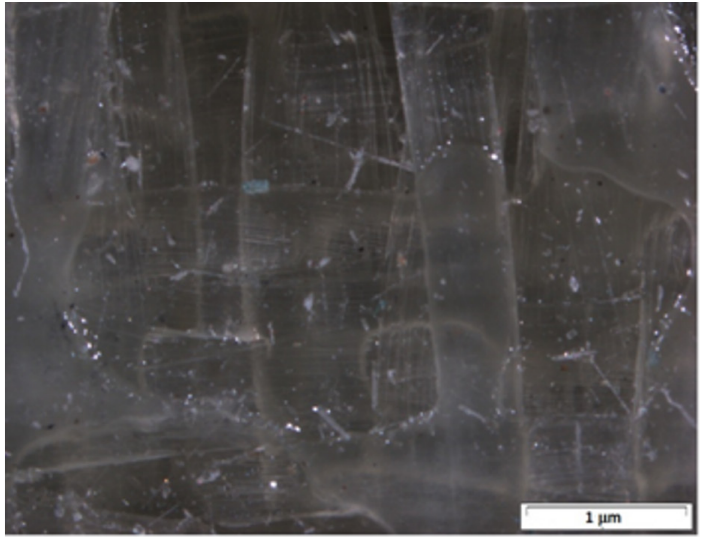

Fig. 8. Surface view of composite IV: $0^{\circ} / 0^{\circ} / 0^{\circ} / 0^{\circ} / 0^{\circ}$ plies arrangement: $a), b)$

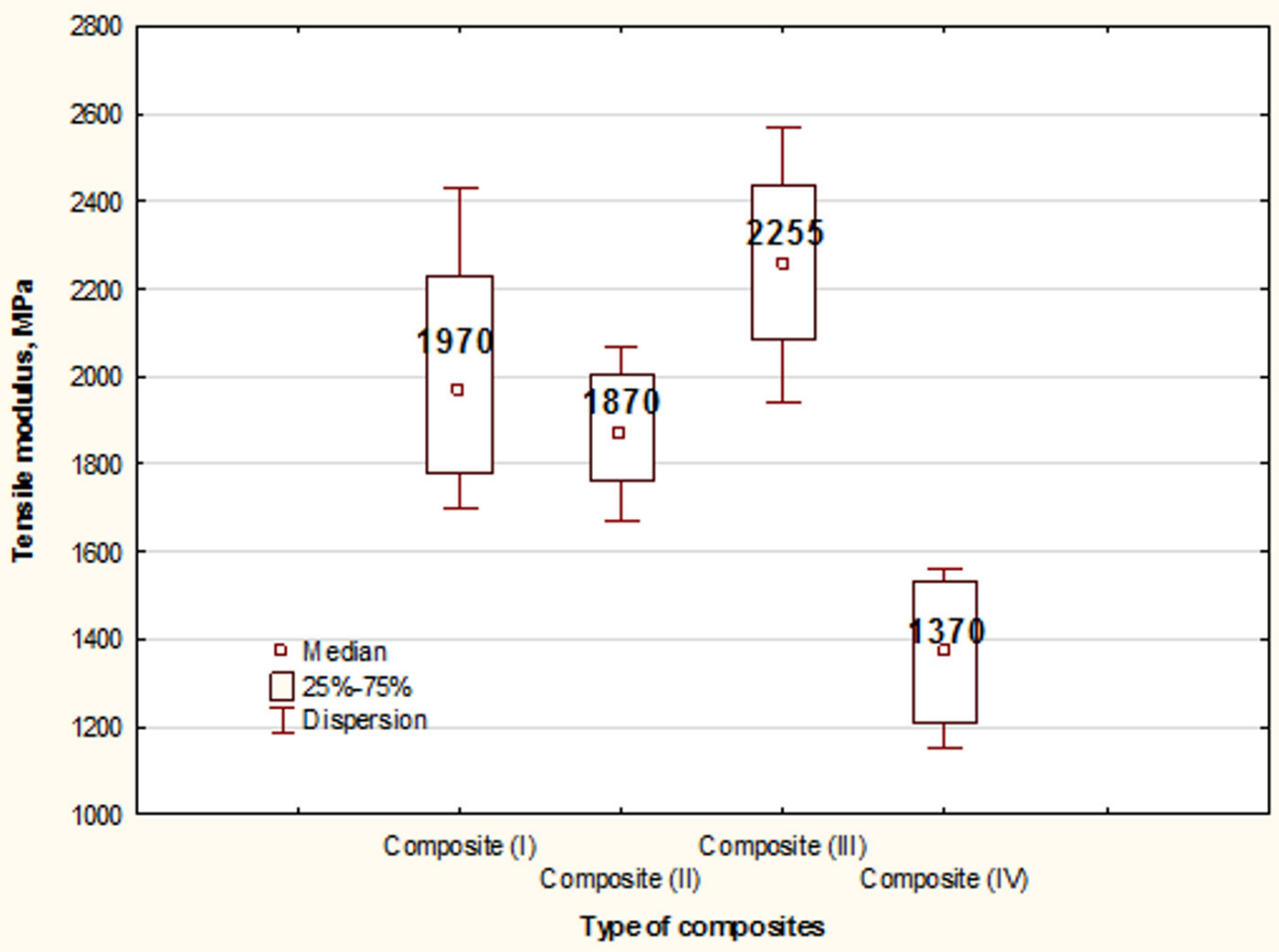

Fig. 9. Tensile modulus of the tested composites samples 


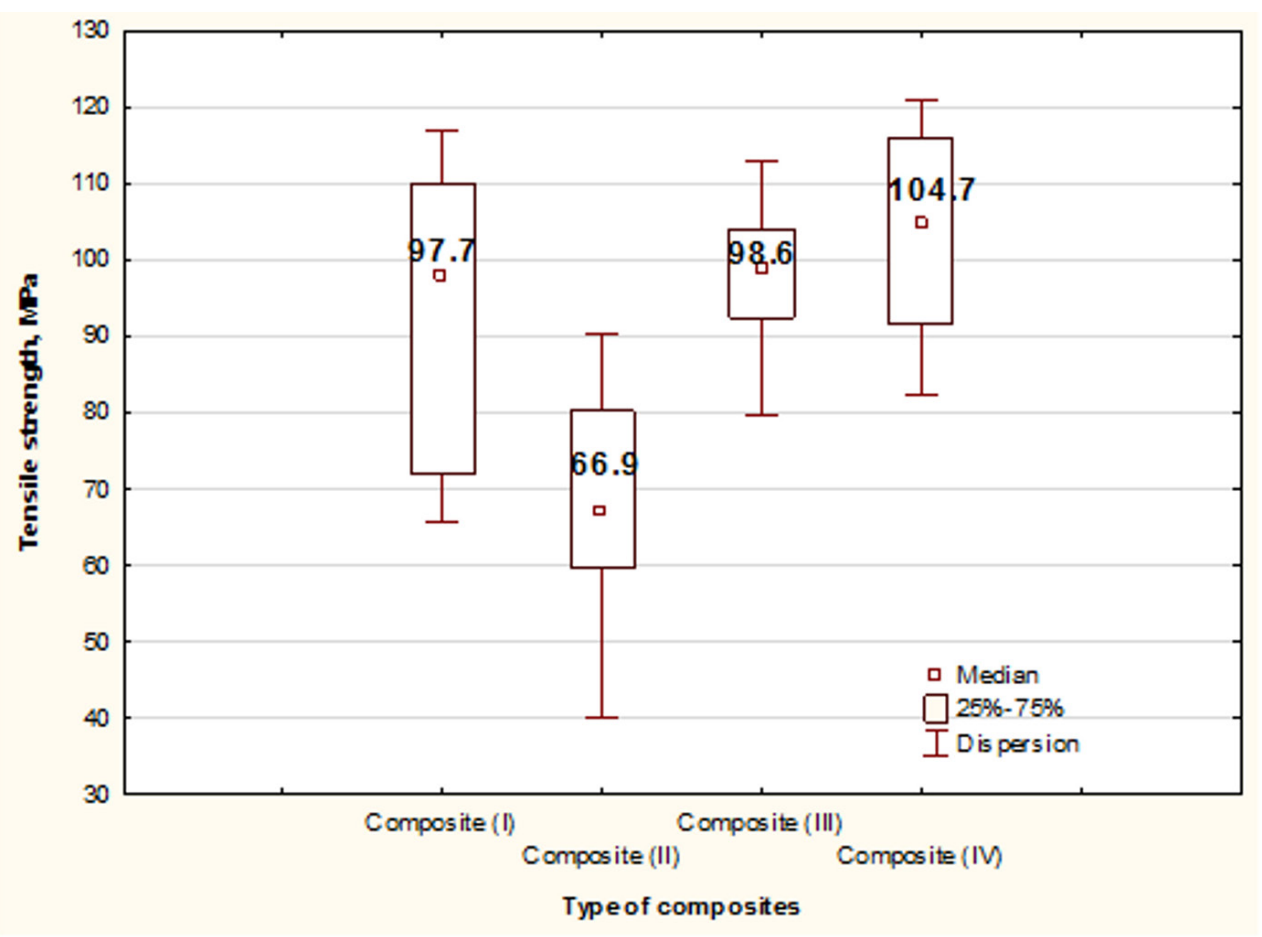

Fig. 10. Tensile strength of the tested composites samples

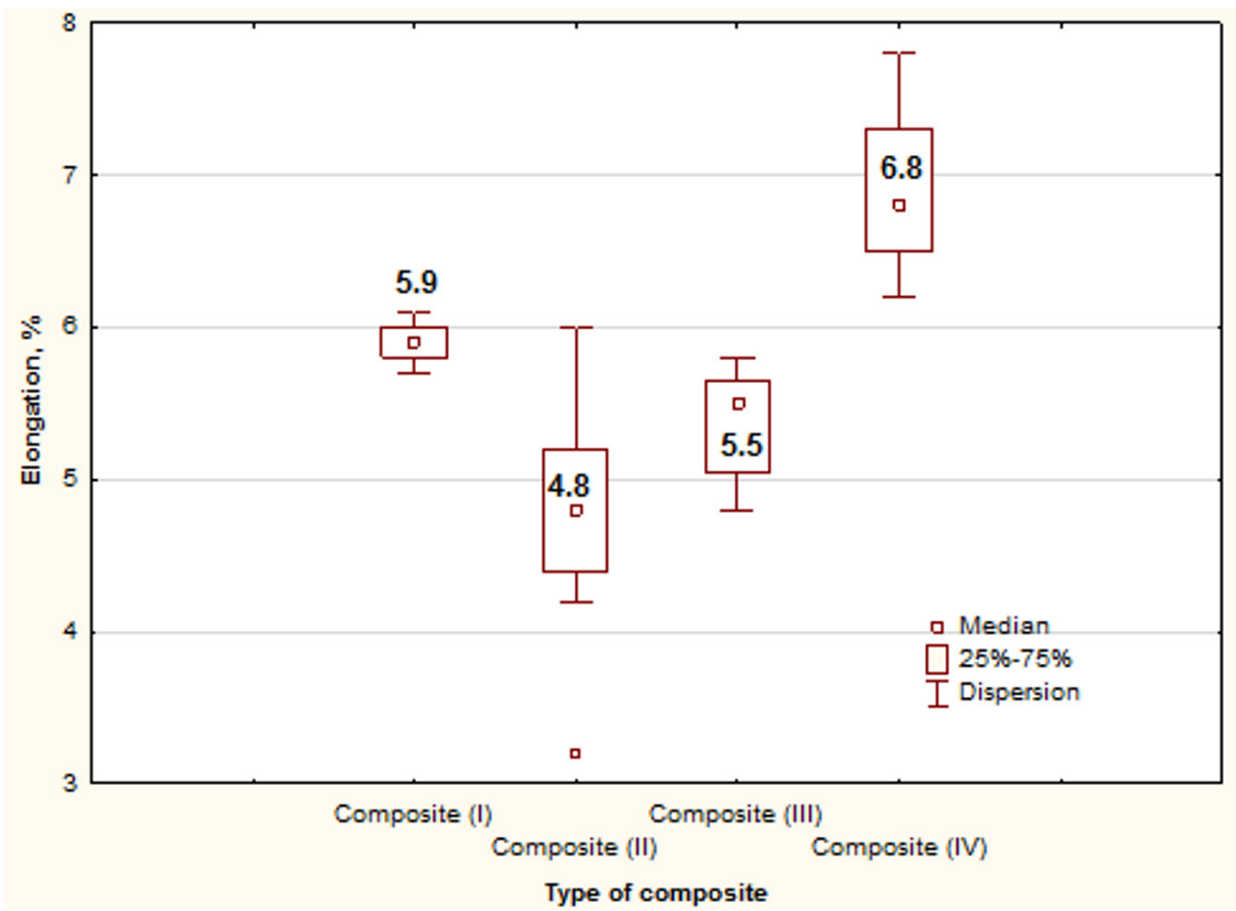

Fig. 11. Elongation of the tested composites samples

$0^{\circ} / 0^{\circ} / 0^{\circ} / 0^{\circ} / 0^{\circ}$ ). The difference is about $40 \%$. Comparing the results of tensile modulus for composites with three plies, the highest value of tensile modulus for Composite III $\left(0^{\circ} / 0^{\circ} / 45^{\circ}\right)$ was obtained while the lowest value of tensile modulus for Composite II $\left(0^{\circ} / 45^{\circ} / 0^{\circ}\right)$. It can be claimed that the central ply of $45^{\circ}$ orientation is disadvantageous. The difference between the tensile modulus value for Composite $\mathrm{I}\left(0^{\circ} / 0^{\circ} / 0^{\circ}\right)$ and Composite II $\left(0^{\circ} / 45^{\circ} / 0^{\circ}\right)$ is $7 \%$. 
The highest tensile strength (Fig. 10) and elongation (Fig. 11) are characteristic for Composite IV, which was the higher the thickness from the tested composite samples. The lowest tensile strength was noted in case of Composite II $\left(0^{\circ} / 45^{\circ} / 0^{\circ}\right)$. In this composite central ply has the $45^{\circ}$ orientation. Comparison the result of composites with $45^{\circ}$ orientation of ply, the higher tensile strength was obtained for Composite III $\left(0^{\circ} / 0^{\circ} / 45^{\circ}\right)$ than Composite II $\left(0^{\circ} / 45^{\circ} / 0^{\circ}\right)$. The differences between these values were above $30 \%$. The near same value of tensile strength was obtained for Composite I $\left(0^{\circ} / 0^{\circ} / 0^{\circ}\right)$ and Composite III $\left(0^{\circ} / 0^{\circ} / 45^{\circ}\right)$. Composite II $\left(0^{\circ} / 45^{\circ} / 0^{\circ}\right)$ has the lowest values of strength parameters among the tested composites, which contain three plies.

The results of elemongation of tested polymer composites have simillar dependence.

\section{CONCLUSIONS}

The paper investigated the effect of plies arrangement in a hand-made composite material on the strength of this composite. The significance of this problem is particularly true these days owing to a wide use of composite materials to design structures with required specific strength. To investigate the effect of plies arrangement on the strength of fibreglass fabric, 4 composite materials were fabricated, each having a different plies arrangement and thickness. Special care was taken to maintain the same manufacturing conditions throughout the entire process as well as to ensure that the composite material be produced with utmost accuracy so as to yield the most reliable results. The stabilizing period of all samples was set to 7 days. After that, each sample was measured and subjected to failure tests. Some of the procedures had to be repeated because of a significant scatter of the results. The final results were then divided into groups to examine the effect of different variants of plies arrangement.

The highest tensile strength and elongation are obtained for Composite IV, which was the higher the thickness from the tested composite samples, but for this composite the tensile modulus was lowest value. Composite II has the lowest values of strength parameters among the tested composites, which contain three plies and central ply has the $45^{\circ}$ orientation.

Concluding, based on the experimental results, plies arrangement vital influences on the strength of composites and should be taken into account when designing composite materials for various applications.

\section{REFERENCES}

1. Adams R.D. (ed.). Adhesive bonding. Science, technology and applications. Woodhead Publishing, United Kingdom, 2010.

2. Baley C., Davies P., Grohens Y. and Dolto G. Application of interlaminar tests to marine composites - a literature review. Applied Composite Materials, 11, 2004, 99-126.

3. Bénard Q., Fois,M. and Grisel M. Influence of fibre reinforcement and peel ply surface treatment towards adhesion of composite surfaces. International Journal of Adhesion and Adhesives, 25, 2005, 404-409.

4. Boczkowska A., Kapuściński J., Lindemann Z., Witembeg-Perzyk D. and Wojciechowski S. Kompozyty. Oficyna Wydawnicza Politechniki Warszawskiej, Warszawa, 2003.

5. Brandt A.M. Fibre reinforced cement-based (FRC) composites after over 40 years of development in building and civil engineering. Composite Structures, 86, 2008, 3-9.

6. Centea, T. Grunenfelder L.K. and Nutt S.R. A review of out-of-autoclave prepregs - material properties, process phenomena, and manufacturing considerations. Composites Part A: Applied Science and Manufacturing, 70, 2015, 132-154.

7. Chand S. Carbon fibers for composites. Journal of Materials Science, 35, 2000, 1303-1313.

8. Czub P., Bończa-Tomaszewski Z. Penczek P. and Pielichowski J. Chemia i technologia żywic epoksydowych. WNT, Warszawa, 2002.

9. de Ulzurrun I.D., López F., Herreros M.A. and Suárez J.C. Tests of deck-to-hull adhesive joints in GFRP boats. Engineering Failure Analysis, 14, 2007, 310-320.

10. Ferdous W., Manalo A., Van Erp G., Aravinthan T., Kaewunruen S. and Remennikov A. Composite railway sleepers: recent developments, challenges and future prospects. Composite Structures, 134, 2015, 158-168.

11. Friedrich K., Zhang Z. and Schlarb A.K. Effects of various fillers on the sliding wear of polymer composites. Composites Science and Technology, 65, 2005, 2329-2343.

12. Grin I. Materiały polimerowe. PWN, Warszawa, 2003.

13. Hatta H., Koyama M., Bando T., Kogo Y., Fukusa $H$. and Ishida $H$. The effects of processing variables on strength of carbon bonding between carbon/carbon composites. Materials Science Engineering A, 513-514, 2009, 138-144.

14. http://www.ciechgroup.com (access on 14-03-2017).

15. http://www.krisko.lublin.pl (access on 12-03-2017).

16. Katnam K.B., Comer A.J., Stanley W.F., Buggy M., Ellingboe A.R. and Young T.M. Characterising 
pre-preg and non-crimp-fabric composite single lap bonded joints. International Journal of Adhesion and Adhesive, 31, 2011, 679-686.

17. Kaye R. and Heller M. Finite element-based three-dimensional stress analysis of composite bonded repairs to metallic aircraft structure. International Journal of Adhesion and Adhesives, 26, 2006, 261-273.

18. Khandan R., Noroozi S., Sewell P. and Vinney J. The development of laminated composite plate theories: a review. Journal of Materials Science, 47, 2012, 5901-5910.

19. Kim S.S. and Lee D.G. Design of the hybrid composite journal bearing assembled by interference fit. Composite Structure, 75, 2006, 222-230.

20. Królikowski W., Kłosowska-Wołkowicz Z. and Penczek P. Żywice i laminaty poliestrowe. WNT, Warszawa, 2002.

21. Kumar P., Singh R.K. and Kumar R. Joining similar and dissimilar materials with GFRP. International Journal of Adhesion and Adhesives, 27, 2007, 68-76.

22. Lee J. and Drzal L.T. Surface characterization and adhesion of carbon fibers to epoxy and polycarbonate. International Journal of Adhesion and Adhesives, 25, 2005, 389-394.

23. Minnetyan L. and Chamis C.C. Progressive fracture of adhesively bonded composite structures. Theoretical Applied Fracture Mechanics, 31, 1999, 75-84.

24. Mouritz A.P., Bannister M.K., Falzon P.J. and Leong K.H. Review of applications for advanced three-dimensional fibre textile composites. Composites Part A, 30, 1999, 1445-461.

25. Oueiny C., Berlioz S. and Perrin, F.-X. Carbon nanotube-polyaniline composites. Progress in Polymer Science, 39, 2014, 707-748.

26. Pang H., Xu L., Yan D.-X. and Li Z.-M. Conductive polymer composites with segregated structures. Progress in Polymer Science, 39, 2014, 1908-1933.
27. Parashar A. and Mertiny P. Adhesively bonded composite tubular joints: Review. International Journal of Adhesion and Adhesives, 38, 2012, 58-68.

28. Rodrigues D.D. and Broughton J.G. Silane surface modification of boron carbide in epoxy composites. International Journal of Adhesion and Adhesives, 46, 2013, 62-73.

29. Rudawska A. Selected aspects of FEM analysis for bonded joints of polymer composite materials. Journal of Physics: Conference Series 628, 2015, 012077.

30. Sabu T., Kuruvilla J., Malhotra S.K., Koichi G. and Sreekala M.S. Polymer Composites, Volume 2: Nanocomposites. Wiley-VCH Verlag GmbH \& Co. KGaA, Weinheim, Germany, 2013.

31. Sengupta R., Bhattacharya M., Bandyopadhyay S. and Bhowmick A.K. A review on the mechanical and electrical properties of graphite and modified graphite reinforced polymer composites. Progress in Polymer Science, 36, 2011, 638-670.

32. Wahab M.A., Ashcroft I.A., Crocombe A.D., and Smith P.A. Finite element prediction of fatigue crack propagation lifetime in composite bonded joint, Composites A, 35, 2004, 213-222.

33. Wahab M.A.Joining composites with adhesives. DEStech Publications, Inc, Lancaster, 2016.

34. Wang C., Huang Y. D. and Wang B. Study on heatresistant property of adhesive/carbon-carbon composite joints. International Journal of Adhesion and Adhesives, 26, 2006, 206-211.

35. Yan L., Kasal B. and Huang L. A review of recent research on the use of cellulosic fibres, their fibre fabric reinforced cementitious, geo-polymer and polymer composites in civil engineering. Composites Part B: Engineering, 92, 2016, 94-132.

36. Zhu J., Zhu H., Njuguna J. and Abhyankar H. Recent development of flax fibres and their reinforced composites based on different polymeric matrices. Materials, 6, 2013, 5171-5198.

37. Żuchowska D. Polimery konstrukcyjne. WNT, Warszawa, 2000. 